\title{
Melting into air: dining in the dark, reification and the aesthetics of darkness
}

\author{
Adam Alston, University of Surrey
}

This is an Accepted Manuscript of a book chapter published by Bloomsbury Academic in Theatre in the Dark: Shadow, Gloom and Blackout in Contemporary Theatre on 27 July 2017, available online: http://www.bloomsbury.com/ BOOK URL: http://www.bloomsbury.com/theatre-in-thedark-9781474251181/

Phosphorescent watches, electric light that seeps from doorframes, the luminous orange of the night-time metropolis that penetrates cracks in blacked-out windows, and (most unbearably of all) tiny green and red LEDs that glow from the back of stage lights and occasionally from the headphones of audiences immersed in the intimate soundscapes of audio-performances: these have all become personal bugbears of a purist craving uncompromisingly complete darkness in theatre. So imagine my delight when I sat down to eat in a restaurant that had successfully evacuated light from its interior, thanks not least to the policed banishment of portable lightemitting devices, all in the service of sensory deprivation.

Once inside, I spent most of the time listening to hubbub, and laughing with my partner as rebellious tomatoes popped off plates after forks failed to pierce their skin. It wasn't long before obsolete cutlery was replaced with hungry but pragmatic hands that revelled in slimily tactile encounters with shellfish, shunning Western social mores in a place that licensed the more frivolous kinds of taboo - the rejection of table manners, especially, alongside the titillating brush of anonymous fingers. And every once in a while, thanks to long communal benches, I would turn to the invisible stranger next to me, or he would turn to me, and we would 
guess the identity of each new morsel, or apologize following the messy novelty of spilled water, or comment on the ability of the waiter - who was blind, as were all the waiters in this particular restaurant - to navigate the space so easily.

Those familiar with 'dining in the dark' may recognize from this description an anecdotal account of attending Dans Le Noir?, which I visited in January 2015 at its Farringdon branch in London. Dans Le Noir? is a global franchise offering employment opportunities to blind and visually impaired people in the commercial sector. Darkness in these restaurants functions as an environmental condition intended to de-familiarize the sensorium for sighted publics, but it is also presented as a (problematic) gateway to sight unseen through an Other's eyes. ${ }^{1}$ The success of dining in the dark restaurants like Dans Le Noir? rests on the appeal of difference and packaged otherness set at a safe distance from one's own everyday experiences, but that nonetheless facilitates fun flirtation with blindness' chimera. In other words, these restaurants build on a tension between ethics and aesthetics, juggling social responsibility and the profitable desire for sensorial exploration among neophile consumers.

I left Dans Le Noir? disappointed and hungry - not for food, but for something transformative. This is because I find a wealth of potential in the possibilities of darkness, as Martin Welton puts it (2013), particularly in societies that have fallen foul of neoliberal individualism in the spheres of both work and leisure. What draws me to darkness is its potential to make us re-think and feel how we perceive and process peopled environments. I think this is important because perceptual, cognitive and social processes are by no means innocent of ideology, which makes me want to identify and explore the influence of a particular set of ideological effects - specifically those linked to the commerce of capitalism - on

\footnotetext{
${ }^{1}$ I am borrowing the phrase 'sight unseen' from Georgina Kleege (1999).
} 
perception, cognition and sociality so as to better understand their ramifications, as well as scope for subversion.

Aside from the bare fact of darkness, communal benches and the option of a surprise menu, Dans Le Noir? offers a remarkably conventional restaurant experience once inside (albeit one that may be responded to extra-ordinarily). The extra-daily qualities of complete darkness are present, but there is no real attempt to explore these qualities. However, Dans Le Noir? does not hold a monopoly on dark dining experiences, which span pedagogic, commercial and social enterprise, as well as theatre and food art - and it is theatre and food art that has tended to evidence a more explorative approach to the aesthetics of darkness, testing how things, people and the environments that house them are made to appear to experiencing subjects, and experimenting with darkness as a compositional element that can possess very different characteristics, and promote very different kinds of effect and affect.

Dining in the dark and theatre in the dark evolved concurrently in Italian Futurism, and as part of theatre and performance festivals in the late twentieth century, including the Avignon Festival in 1993 and Battersea Arts Centre's Playing in the Dark festival in 1998. However, such links are largely unaccounted for in relevant scholarship, which focuses on social and commercial dining in the dark enterprises ${ }^{2}$ that run the risk of reifying, rather than defamiliarizing, how acts and objects of perception 'appear' to beholders in the dark, and assumes that the bare fact of immersion in darkness is enough to stimulate both a recalibration of the

\footnotetext{
${ }^{2}$ Charles Spence, Caroline Hobkinson, Alberto Gallace and Betina Piqueras-Fiszman (2013) reference Italian Futurism and Hobkinson's food art, but focus on tactile encounters with food in lit spaces. Spence and PiquerasFiszman do address dining in the dark elsewhere (Spence and Piqueras-Fiszman 2012), but limit attention to commercial contexts. Siegfried Saerberg also refers to 'Blackout - a performance in absolute darkness' (1992) by Blinde und Kunst e. V., but this appears to be a music and story-telling event set in darkness, which included the serving of drinks, rather than theatre in the dark or dining in the dark, specifically (Saerberg 2007: n.p.).
} 
senses and a reconfiguration of social relationality. This chapter identifies these as ambitious aims, and argues that they lend themselves more to the playing space between experimental theatre and food art than they do to the commercial sector.

The next section sets out a brief history of dining in the dark since the 1990s, which is a decade that propelled (without originating) a wave of interest in dining in the dark events; however, it does so by setting out the co-evolution of theatre in the dark and dining in the dark. The section after that offers a framework for what I'm calling a 'critical theory of darkness', which draws on and frames the Marxist theory of reification as an aesthetic concept of relevance to a critique of dining in the dark restaurants like Dans Le Noir? The penultimate section looks back to Italian Futurism for an example of a dining in the dark event that straddles theatre and food art, addressing the aesthetics of darkness in ways that might resist the reifying impulses of capitalism, at least those of the time. And a final section reflects on the continued relevance of reification in postindustrial societies where no-thing - where darkness - poses as a unique selling point. Returning to the fruitful interplay between food art and theatre, this time in more recent history and in light of compromises charted throughout the chapter, I explore how the artistic sphere carries the best potential for de-familiarising acts and objects of perception in completely dark contexts. Has reification reached an apogee in the postindustrial culture industry, objectifying human relationships that serve not only the production of material goods, but the alluring immateriality of darkness as well? And what scope is there today to recalibrate the core media of political economy, and of dining in the dark: the appearance, disappearance and representation of social relationships? 


\section{Dining in the dark since the 1990s: scholarly preoccupations and the retrieval of theatre}

The first scholarly text to be published focusing specifically on dining in the dark was Siegfried Saerberg's 'The Dining in the Dark Phenomenon' (2007). His argument is typical of claims made by many dining in the dark restaurants formed during or shortly after the 1990s as social enterprises, exploring how communal experiences of complete darkness can promote insight into the social construction of disability, especially as the result of verbal communication between sighted consumers and the blind and visually impaired labourers who serve them as waiters. Saerberg's research aligns with other blind writers who challenge the misleading conflation of darkness and blindness (see Kleege 1999; Magee and Milligan 1995; Michalko 1999) - and is in this sense very useful - and it also builds on his own experience of working with relevant social businesses and special events. However, it is worth exploring other salient features associated specifically with darkness that move beyond a critique of simulation, while expanding the fairly narrow historical and geographical reach of this article. In response, I will be challenging Saerberg's identification of a singular dining in the dark movement, which in his articulation largely limits scope to German initiatives emerging just before and after the turn of the twenty-first century, turning instead to a broader sweep of practices that propose alternative approaches to the 'recalibration' of sensory perception and sociality.

A second and more recent article worth highlighting is by Tim Edensor and Emily Falconer, titled 'Dans Le Noir? Eating in the dark: sensation and conviviality in a lightless place' (2015) - an article that also focuses on dining in the dark as a social enterprise, this time solely as a commercially-run social enterprise. 'Repetitive, everyday sensual experience', they write, 'occurs in familiar spaces that constitute a stable backdrop to habitual practices of work, leisure and rest, routine tasks accomplished with little reflection, unless we are alerted to the possibility that things might be out of place' (2015: 602). De-familiarization - a canonical tactic in Marxist aesthetics - is meant to counter such a backdrop by alerting subjects to the 
over-looked and taken-for-granted. Edensor and Falconer are largely supportive of the 'sensory alterity' that Dans Le Noir? purports to offer its diners by putting perception 'out of place', but I'm not as convinced about the depth of this alterity and its departure from 'normative apprehension' (2015: 602-03). This is because Dans Le Noir? does not engage with a very particular circumstance that impacts on sensory cultures: the effects of commerce on sensory experiences under capitalist conditions of production and consumption. Light is displaced, which requires some degree of sensory reorientation, but normative apprehension is not affected all that much, particularly the normative apprehension of social relationships - at least, that is the argument that the rest of this section builds towards, and that the next unpacks.

While they found an important precursor in Italian Futurism, dining in the dark initiatives did not gain any real momentum until the 1990s when it re-surfaced in 1993 as a social enterprise looking to enhance understanding among sighted publics about the lived experiences of blind and visually impaired people. This resurfacing was linked to Andreas Heinecke's travelling installation Dialogue in the Dark, which began as an experiment at the Foundation for the Blind in Frankfurt in 1988, before a fully-fledged exhibition opened in Dusseldorf in 1989. The installation aims to develop understanding of blindness and visual impairment by immersing visitors in a series of pitch-black installations based on spaces found in the host city. Dining in the dark offered another 'edge' to the Dialogue in the Dark experience. The first dining in the dark event affiliated with Dialogue took place in 1993 as part of the Avignon Festival's Dark/Noir season, which programmed a range of performances coalescing around the exploration of light and darkness. Produced by Michel Reilhac, food and drink was offered for consumption in total darkness under the guidance and service of blind and visually impaired waiters, which went on to form the model for Reilhac's Parisian pop-up restaurant Le Goût du Noir (A Taste of Darkness) six years later. 
1993 is a key year for both theatre in the dark and dining in the dark, as Dark/Noir marks the first occasion that a programme of work addressed the aesthetics of darkness in any kind of coherent way. Furthermore, Reilhac's participation in Dark/Noir provided June Bretherton of the Bretherton Consultancy and Martin Gent of dA dA dUMB with a model for Dark Dinners, which featured in the second major festival of theatre in the dark after Dark/Noir: the Battersea Arts Centre's 1998 Playing in the Dark festival. Bretherton and Gent had previously collaborated when Dialogue visited London's Royal Festival Hall in 1995, and they were both campaigners for enhancing awareness and understanding of blindness at the time (Gent 2014). Reilhac's influence is clear, as is the link between dining, darkness and theatre within a themed programme of work, which begs the question: What is it that lends each to the other?

Going to 'see' a show has a historical connection to social gatherings that centre around food, particularly through the custom of discounted pre- and post-show meals. But at both Dark/Noir and Playing in the Dark the social patterning of meal-based gatherings were rerouted into a curated context, the common theme of which was darkness and hence the inhibition of sight. Theatre-going ordinarily exceeds the timeframe of a performance once conceived as 'an event', but the curation of festivals like Dark/Noir and Playing in the Dark problematize smooth distinctions between daily and extra-daily activities by positioning the sociality of dining neither prior to, nor after, but within the context of a programme of performance. Theatre festivals like these are patently susceptible to the material conditions of production and consumption; nonetheless, the integration of dining in the dark within each opens up scope to play with how audiences consume, and with connections between patterns of consumption and the ordering of the senses. However, there is much ground to cover before unpacking such scope in the final two sections of the chapter. 
The shared evolutionary heritage of dining in the dark and theatre in the dark has not always shared a stage within curated programmes; rather, dining in the dark has also emerged as an adjunct alongside such programmes. For instance, the Nalaga'at centre in Tel Aviv, which was set up in 2007, is a non-profit organisation for deaf, blind, deaf-blind and general public artists and audiences. A dining in the dark restaurant called BlackOut is now a permanent fixture at the centre to be attended before or after a performance. A slightly different example comes from the Argentinian collective Teatro Ciego (Blind Theatre), which was founded in 2001 at the Centro Argentino de Teatro Ciego in Buenos Aires. Teatro Ciego have been running A Ciegas Gourmet since 2008, which picks up on Reilhac's now influential model - making sighted diners dependent on the guidance of blind and visually impaired waiters - only it resembles more closely the North American tradition of dinner theatre, albeit set in complete darkness. Teatro Ciego and the Nalaga'at centre both conform to fairly conventional social patterns - dinner and or with a show - rather than experimenting with the artistic potential of dining in the dark itself. While I do not want to take anything away from the valuable work of either company as social enterprises, I find myself wondering whether a more radical potential for de-familiarization is missed that relies less on the bare novelty of darkness.

To get to the root of dining in the dark's de-coupling from theatre in the dark, as well as what this means for 'a more radical potential for de-familiarization', it is necessary to engage with the transformation of dining in the dark from a social enterprise into a global franchise. In 1999, the same year that Reilhac launched his pop-up restaurant Le Goût du Noir, Blindekuh (meaning both 'Blind Cow' and 'Blind Man's Bluff') was founded in Zurich as the first permanent dining in the dark restaurant, laying the foundations for a more commerciallyoriented set of initiatives. It was set up to give 'sighted people an insight into the experience of being blind', while facilitating job creation for visually impaired people (Blindekuh 2015). Two German restaurants followed shortly afterwards: unsicht-Bar (Invisible Bar) in Cologne 
in 2001, and Nocti Vagus and a second unsicht-Bar in Berlin in 2002. But it is Dans Le Noir? that has ended up as the biggest commercial success. Dans Le Noir? now has permanent branches in London, Paris, Barcelona and St. Petersburg, and temporary restaurants have popped up in Moscow (2006), Lille (2007), Warsaw (2008), Bangkok (2008 and 2010), Geneva (2009), New York $(2011 / 2013)^{3}$, and Riyadh (2013) (see Dans Le Noir 2014). The Parisian branch was the first, founded by the social entrepreneur Edouard de Broglie, in cooperation with Etienne Boisrond. It opened in 2004 with the support of the Paul Guinot Foundation for Blind People, which is a charitable organisation that also supported Reilhac's Le Goût du Noir five years earlier. However, Dans Le Noir? was always intended by de Broglie as a company that could transform social responsibility into a profitable business capable of employing a large number of visually impaired and blind people in a visionist labour market, and it now self-supports as a private company (de Broglie 2015).

What is de-familiarized, if anything, in the darkness of Dans Le Noir? It seems to me that the social construction of disability - the very thing that's intended to be de-familiarized in this franchise, and restaurants like it - is not de-familiarized at all, or at least all that much. This is because a more fundamental layer of appearance remains intact that is linked to the lack of an experimental approach to the aesthetics of darkness, taking for granted its impact on acts and objects of perception, and especially social relationships between consumers and blind and visually impaired workers. To unpack the reasons why, I want to return to an idea that until recently had fallen out of fashion: the Marxist concept of reification.

\footnotetext{
${ }^{3}$ The New York restaurant was not intended as a pop-up; rather, and surprisingly, it failed to make enough money to sustain itself.
} 


\section{Reification in the commercial sector: toward a critical theory of darkness}

Inspired partly by Marshall Berman's (1983) reading of Marx as a modernist writer, I find myself drawn to the descriptors used in conceptualising reification: terms like 'disappear', 'invisible', 'ghostly objectivity', 'phantom objectivity', 'concealment', 'veil', and 'disguise' (Marx 1995: passim; Lukács 1971: 83-100; Honneth 2008: 32; Chari 2015: 114). These terms have accrued special significance in the present moment, evidenced by a turn to immaterial modes of production in postindustrial societies and, more narrowly and literally, in the commodification of darkness. Moreover, they lend themselves to aesthetic scrutiny. Theories of reification frame capitalism as an ideology premised on the concealment of the labour process, which has as much to do with the formal and relational composition of a commodity and its appearance to beholding consumers as it does with economics. This is what leads me to suggest that reification has an aesthetic character (see also Bewes 2002: 107-10), implying a need to dig down into notions of appearance, and the hidden dimensions of objects, or objectified subjects.

In his unfinished masterwork Capital: Critique of Political Economy (1867-83), Karl Marx identifies social relations in capitalist societies as the source of a commodity's value, defining commodities - the fruits of labour - as a mediator of relationships among workers that only manifest indirectly after labour-power is sold and wages are exchanged for the material necessities of existence, such as food and shelter. To the producers of commodities, "the relations connecting the labour of one individual with that of the rest appear, not as direct social relations between individuals at work, but as what they really are, material relations between persons and social relations between things' (Marx 1995: 44). Consequently, the labour process 'disappears in the product' (ibid: 118), and is incorporated 'as a living ferment, with the lifeless constituents of the product' (ibid: 120). For Marx, the incorporation of a disappearing labour process is what animates commodities. At the points of exchange and consumption, the social 
relationships between people that go into a commodity's production transform into social relationships between things.

The obfuscation of social relations and their displacement to relationships between things is what Marx calls 'commodity fetishism', but it also forms the basis of the Marxist theory of 'reification' - a term most closely associated with György Lukács's History and Class Consciousness (1971), which is a collection of essays first published in 1923. ${ }^{4}$ Lukács's analysis of reification adapts the theory of commodity fetishism by focusing on the subject positions of social agents. For Lukács, reification describes both the objectifying effects of interactivity among social agents across capitalist societies as a result of pervasive commodity exchanges within them, and an interpretative habit inculcated by these societies that tends toward the objectification of people and the world they live in. As Anita Chari neatly summarizes, the Lukácsian notion of reification 'focuses on the interplay between subjective experience and political economy' (2015: 62), and describes a veiling of social relationality that results from commodity exchange, as well as an objectifying mode of perception that becomes habituated as a kind of second nature.

I want to draw on the concept of reification in putting forward a critical theory of darkness, but such a project is not without issue. Lukács's Hegelian leanings were repudiated by Structuralist Marxists in the early 1960s (see especially Althusser 2005: 230), and more recent critical attention has targeted his essentialist and normative proselytizing of a 'universal' class - the class of the proletariat (Chari 2015: 121). As Judith Butler points out, the revelation of a more 'genuine', 'truthful' or 'idyllic' set of social relations that precede capitalist appropriation risks disregarding the inequities associated with historical precursors such as

\footnotetext{
${ }^{4}$ The study of reification is also indebted to the first wave of the Frankfurt School and the European New Left. For an instructive overview see Jay (2012: 4).
} 
feudalism, on the one hand, while asserting normative relationships and ethical demands, on the other (2008: 104). However, provided that social relationality under capitalism is not pitched against a more 'essential' and 'natural' social order, and that we recognize that there are myriad configurations that a social order might adopt, then applying the concept of reification as a critical tool is still valuable if it can inform understanding of the influence of capital on perceptual experience and cognition.

As Marx and Friedrich Engels anticipated in The Communist Manifesto, capitalist relations of production and consumption evolved over the course of the twentieth century with the advent of Fordism, followed by the ascendency of the service economy in national and international markets, and most recently the experience economy, of which Dans Le Noir? is certainly a part. 'All that is solid melts into air', they wrote, but quite how prescient and literal a spin this was to have might have surprised them (2002: 223). The unique selling point in dining in the dark restaurants is darkness, which is an attractive commodity because of its ability to make familiar things disappear from view. That's its draw. It is not just the disappearance of 'the real conditions of life' that need to be retrieved in its study, but the disappearance of the very things, commodities, that derive value from these conditions (ibid).

While the employment that Dans Le Noir? offers to its blind and visually impaired workers is a good thing, the generation of surplus value that is required for a commercial business to evolve into a global franchise carries important ramifications for the commodification of darkness and the kinds of social relationality that can occur under its veil. The labour of the waiting staff is present to customers who depend on their guidance, but the 'pull' of the dark - as a talking point, novelty and spectacle - takes precedence once framed as a core attraction. Reification is at work. What's more, the kinds of social relation that are forged are no different to the more dominant kinds of social relation that can be found elsewhere in capitalist societies; they are still mediated by commodities. Dans Le Noir? does seek to 
undermine visual culture, but it does not affect the dominant mode of transforming social relationships in capitalist economies - reification - and fails to recalibrate a more fundamental framework on which the appearance and disappearance of social relations is based.

Dans Le Noir? evidences how no-thing can be marketed, but since its emergence darkness has also come to be used as a marketing device put in the service of material goods. For example, in July 2015 Coca-Cola Middle East launched an advert featuring six strangers who were invited to participate in an 'Iftar in the dark' held at the Fairmont Hotel in Dubai. The advert sought to redress prejudicial assumptions about the visual appearance of people, adding a layer of connotative meaning to an aesthetic of darkness that's of some relevance to its critical theorization. 'I read a lot of books. I read cognitive psychology. I read behavioural science', says one of the diners, before an infrared camera reveals to the viewer a MiddleEastern man, in his mid- to late-30s, perhaps, with tattoos covering most of his face and shaved head. This man is Loy Machedo, a personal branding strategist (Machedo 2015). A little later, one of the participants describes himself as an extreme sports athlete before a caption appears: 'We then switched the lights on'. The camera surveys the table from behind his wheelchair, before each of the participants describes how shocked they are by the appearance of one another. Finally, they are asked to reach beneath their seats where a box is waiting containing two limited-edition label-less cans. The closing tagline: 'This Ramadan see without labels'.

The 'see without labels' campaign plays into the hands of reification as an 'interpretative habit' that springs from the 'the interplay between subjective experience and political economy' (Chari 2015: 62) - only not at the point of a material good's production, but its marketing. This is because the advert, despite its best intentions, does not so much undermine as substantiate the attachment of prejudice to the visible markings of race, ethnicity and disability; visuality is crucial in the advert's logic, which objectifies the participating subjects by isolating and harnessing each of these markings to hammer home the message that 
labels are not for people, but for a commodity that mediates and is 'animated' by their interactivity. It is also noteworthy that women do not feature at all in the advert, which is striking in a purportedly anti-prejudice campaign. This is most likely because of the (variable) interpretation and application of Sharia law in several Middle Eastern countries, which limits the kinds of interaction that women are permitted to have with men, and the ways in which women are entitled to appear in public. ${ }^{5}$ Nonetheless, by anticipating criticism from the more conservative arms of Islam, the advert ends up sustaining concealment of the very subject who stands to benefit most from this kind of platform.

The 'see without labels' campaign subsumes tension between the commerce of sociality and the commerce of buying and selling, and in looking to foster an empathic understanding of alterity it solidifies the very sensory framework that forms the brunt of its critique: ocularcentrism. The irony here is that the advert deploys light, so often associated with whiteness and steeped in ideology, as a means of revelation. In mediating a strange experience of darkness via illuminated screens, the campaign figures the aesthetics of darkness - in both its literal and connotative guises - as a fully-reified spectacle abstracted from its conditions of production. Comparably, Dans Le Noir?, while clearly distinct from the campaign given its grounding in a live encounter, nonetheless shares in the reification of subjectivities pitched as Other; in both cases, alterity is encountered through fairly conventional means that neither test those means - as aesthetic conditions of production and reception - nor de-familiarize the objectification of the subjects they claim to re-frame.

\footnotetext{
${ }^{5}$ My thanks to Loy Machedo for his informative emails in January 2016.
} 


\section{The electrical illumination of Italy and the Tactile Dinner Party}

Avant-garde precursors to the rising tide of dining in the dark initiatives in the 1990s have adopted less complacent approaches toward its de-familiarizing possibilities by exploring the aesthetics of appearance and disappearance at the tail end of a particularly interesting point in the histories of capitalism, sensory perception and social relationality. I have in mind the commercialization and globalization of electric lighting in the late-nineteenth and earlytwentieth centuries, which mark a period when a highly effective artificial light was newly omnipresent, and a period when the visual appearance of things and people came to form a relatively novel link with capitalism.

Thomas Edison and his co-workers were vital contributors to the commercialization of electric lighting and its widespread instalment as a utility, not least because of the 'backing of established financiers willing and able to bring his ideas to market', such as J. P. Morgan (Hausman, Hertner and Wilkins 2008: 11). ${ }^{6}$ Edison founded a long string of light and power companies in his own name in countries around the world between 1880 and 1883, including Italy; Società Generale Italiana di Elettricità Sistema Edison was founded in Milan in 1883 and soon became Italy's leading electric utility. While the company ultimately ran independently of Edison's ownership and control, and received foreign investment from European banks through the Banca Commerciale Italiana, its initial links to Edison and Morgan nonetheless signal the reach of foreign capital into nascent electricity industries.

Italy witnessed a remarkably high growth rate of 18.6 per cent in per capita electricity production between 1900 and 1918 (see Hausman, Hertner and Wilkins 2008: 26, 80, 85), and it was within this period that Filippo Tommaso Marinetti founded Italian Futurism in 1909.

\footnotetext{
6 Thomas Edison did not invent electric lighting, but rather participated in an international wave of experimentation in its physics and chemistry throughout the nineteenth century (see Palermo 2014).
} 
Italian Futurism was inspired by: industrialization and the commercialization of newly emerging technologies, not least lighting technologies; the industrial and commercial applications of the theories of light, metallurgy, chemistry, electricity and electromagnetism; the incessant enhancement and revision of these theories and applications; and their impact on metropolitan life, which followed a fairly belated Industrial Revolution in Italy in comparison with other western European countries (see Berghaus 2009: 2). Italian Futurism was ignited by innovation, and electric light was its beacon.

Gas lighting inspired some of the earliest modernists, notably Charles Baudelaire (see Berman 1983: 90), but none celebrated the aesthetics of light in modern life as ardently as the Italian Futurists after the proliferation of electric lighting. ${ }^{7}$ Marinetti desired to murder the moonlight' (2009b: 59), eulogizing electrical advertising signs 'obdurately opposed to the desperation of darkness [...] sickly twilight, the nostalgic moon, and the stars so abounding in depressing melancholy' (2009a: 282, original emphasis). Indeed, these electrified advertising signs exemplify the pact that was being forged between science, technology, and commerce at the time, and 'the new Futurist aesthetic' (ibid) mined its consequences as creative stimuli.

As for Futurist theatre, darkness tended to serve as a counterpoint to the captivating brilliance of electric light. A good example is Francesco Cangiullo's play Luce! (Lights!) (1919), which begins by immersing audiences in complete darkness for a period of ' 3 BLACK minutes', with members of 'the PUBLIC' shouting 'Lights!' until 'THE ENTIRE THEATRE' is roused into a 'wild, crazy' state of obsession for light, at which point 'The stage and auditorium are illuminated in an EXAGGERATED way', just as the curtain 'slowly falls' (qtd

\footnotetext{
${ }^{7}$ Giacomo Balla's Iridescent Interpenetrations (1910s) provide the clearest examples, along with his replacement of dancers with coloured electric lights in his set design for a production of Igor Stravinsky's Feu d'artifice
} (Fireworks) (1908) in 1917. 
in Kirby 1971: 254). In this example, which marks an early instance of theatre in the dark (putting to one side a longer history of experimentation with shadow, gloom and the dimming of theatre auditoria), the aesthetics of darkness is toyed with - but only as a foil to be vanquished by electric light. ${ }^{8}$

Luce!, as a milestone in the history of theatre in the dark, came from a movement that also birthed an early example of dining in the dark - and it is the latter, particularly in an example that traverses both, which marks out a direct and rare embrace of darkness in Italian Futurism. The example I have in mind is taken from The Futurist Cookbook, which features a 'formula' by Fillì for a Tactile Dinner Party. The Cookbook describes Fillì's plans - whether or not they materialized is unclear, but if they did the dinner probably would have taken place in 1930 or 1931 (Berghaus 2001: 14) - to invite participants into a darkened room wearing pyjamas 'made of or covered with a different tactile material such as sponge, cork, sandpaper, felt, aluminium sheeting, bristles, steel wool, cardboard, silk, velvet, etc. [...]: without being able to see, each guest must choose a dinner partner quickly according to his tactile inspiration' (Marinetti 2014: 170). ${ }^{9}$ Having selected a partner in the dark, guests make their way into a dining room where a banquet begins that includes dishes designed to challenge the diner's sensorium: for instance, a 'Tactile Vegetable Garden', to be eaten by 'burying the face in the

\footnotetext{
${ }^{8}$ See also Augusto Mauro's Morte e Trasfigurazione (Death and Transfiguration, 1920), which treats 'sensitive darkness' as a backdrop for vibrantly coloured lights (see Kirby 1971: 296), Paul Frischauer's expressionist play Im Dunkel (In the Dark) (1924) (see Elcott 2016: 169), and the broad range of historical examples featured in this book’s Introduction.

${ }^{9}$ Several of these materials are specified in Marinetti's manifesto on 'Tactilism' (1921) (see Marinetti 2009c: 266-7). Interestingly, Marinetti dismisses the value of immersing participants in darkness in the manifesto, believing it would bring about a lesser form of tactile experience.
} 
plate, without the help of hands, so as to inspire a true tasting', all accompanied by perfumes sprayed into the faces of diners (ibid: 171).

Fillìa turned to darkness as a stimulant for a mode of encounter attuned to invisible forces, proposing a new relationship with the sensorium well-suited to scientific discoveries that eluded perception by the naked eye (see also Pietropaolo 2009). However, in doing so, he also turned his back on an important aspect of modernity that spread rapidly as a result of commercialism and globalization: electric light, which by that time had become domesticated and integrated into the municipal and industrial spheres. By evacuating light - including and especially electric light - from an experiment within a movement inspired by its radiance, Fillìa enacted a symbolic attack on the relationship that Futurism had forged with capitalism, recognizing that electric light remained dependent on private energy providers until the nationalization of Italy's electricity sector in 1962 (later re-privatized in the years just before and after the turn of the twenty-first century). ${ }^{10}$ Electric light in the networks of capitalist commerce could be bought and sold like any other commodity, and had taken the form of an object well-suited to labour after dark. In facilitating the commonplaceness of commercially viable electric light, capitalism co-opted the means by which eyes could see clearly and pristinely throughout the day and night, which in visual cultures deeply affects the appearance of the world to its spectators. In other words, light, and the social relationships that had come to participate in its production and consumption as a commodity, became reified. But in depriving spectators of the ability to see anything other than darkness, and by encouraging a more holistic engagement with the senses, Fillìa took on the politically-imbued mediation of

\footnotetext{
${ }^{10}$ Fillìa had previously contributed to the Futurist mainstream by glorifying electric light - for instance, in his 1927 play Sensualità Meccanica (Mechanical Sensuality). The Tactile Dinner Party was therefore innovative not just within the broader context of Italian Futurism, but Fillì's oeuvre as well.
} 
appearance - no longer filtered through the commodity of electric light, but through a more nuanced engagement with the world as it appears in the nostrils, on the tongue, and at the tips of fingers. Commerce as an economic activity was consequently substituted for the commerce of sociality as participants sought tactile inspiration from communal interactivity, alongside an encouraged exploration of the sensorium. In other words, Fillìa concerned himself with the social possibilities of darkness in a scenario that collapsed theatre in the dark and food art, turning the 'culinary' publics of restaurant culture into an experimental social gathering that toyed with a sensus communis.

Contextualized in the commercial activities of capitalism, light becomes both a reified and reifying entity; light is put in the service of an ideology interested in more than just its use value, ultimately resulting in the connection of capital to perceptual experience. This is what makes the Tactile Dinner Party so interesting, as it presented an implicit challenge to the reified and reifying characteristics of commodified light by questioning the alliance that Futurism had established with capitalism through a fairly novel embrace of darkness. At the threshold of food art and performance, Fillìa's Tactile Dinner Party revealed the potential - albeit a potential that probably did not inform the project's creation - to enact a radical unbinding of perceptual experience from an ideology that found itself able to profit from an ocularcentric culture. This potential may well have been arrived at by accident, but it nonetheless signals the kind of unpredictable (and for that reason potentially subversive) values that experiment can procure when faced with the reifying tendencies of commercial capitalism.

\section{Darkness that dances: between food art and theatre}

As Chari recognizes, postindustrialism has transformed the economy and modes of work in ways that Marx and Lukács could not have anticipated, despite prescient insight, which should 
make us at least a little 'skeptical of the usefulness of the paradigm of reification for describing contemporary economic and political subjectivity' (2015: 128). Postindustrial societies are not governed by the same Taylorist principles that informed Lukács's writing and contextualized Fillìa's Tactile Dinner Party; instead, as has been well-documented in sociology and political philosophy, labouring subjects 'are increasingly called upon to become active, enthusiastic, and entrepreneurial' (Chari 2015: 128), as are consumers who now participate in the modelling or adaptation of products and staged experiences (see Pine and Gilmore 1999). However, in my view - which is a view shared with Chari and others (see, for instance, Bewes 2002; Honneth 2008; Crary 2013: 99-105) - the advent of postindustrialism has made theories of reification even more useful and illuminating. This is especially so when we take into account biopolitical studies of political economy that address the instrumental handling of corporeal experience in neoliberal economies (see for instance Hochschild 1983; Hardt 1999; Illouz 2007). The difference is that these more recent studies turn attention toward more contemporary issues that are no longer tied to the production of physical things; instead, they address immaterial phenomena such as affects, emotions, feelings, and experiences that become 'thing-like' - and thus reified - without materializing as a physical entity. Such a shift makes it all the more important to consider reification's relevance as a theory fundamentally concerned with subjective experiences of capitalism.

On the basis of the examples surveyed in this chapter, it seems that dining in the dark's most promisingly subversive potential rests at the threshold between food art and theatre. But what other, more recent, examples straddle this threshold, now that the context that inspired Italian Futurism has changed so fundamentally? While several permanent dining in the dark restaurants have developed cultural programmes that include live theatre and concerts, including Blindekuh and Nocti Vagus - and, as Maria Oshodi and Amelia Cavallo explore in their contribution to this volume, Dans Le Noir? as well - these tend to offer dinner and or with 
a show, comparable to Teatro Ciego and the Nalaga'at centre, rather than experimenting with the aesthetic possibilities of dining in darkness. However, a number of theatre and performance makers have been toying with food art and theatre in work for dark environments over the past two decades. Several of Caroline Hobkinson's immersive dining experiences either took place in darkened spaces, or incorporated the use of blindfolds, and have directly referenced Italian Futurist banquets (see Hobkinson 2014). Enrique Vargas and the Barcelona-based collective Teatro de los Sentidos have also been creating multi-sensory performances over the past two decades, most notably with their touring production in the dark La Bodega de los Sentidos (The Cellar of the Senses) (2006-13). Beth Hogan's contribution to the first of the Odyssey Theatre's Theatre in the Dark (2012) programmes in Los Angeles - which were directly inspired by the BAC's Playing in the Dark festival (Essex-Lopresti 2015) - saw audience members reaching beneath their seats in a fully-darkened auditorium to find bags containing food for an 'eat along'. And Dana Salisbury's Dark Dining Projects, founded in 2005 in New York, mark an especially close relation to Reilhac's dark restaurant model, only shorn of a clear ethical agenda, and replacing darkness with blindfolds. Dancers lead guests to tables, and audible performances in a range of styles unfold throughout, such as beat boxing, tap dancing, and body percussion. However, it is the work of Alicia Ríos that I want to dwell on in what remains of this section. Her sensory concerts performed in London, Madrid, Alcalá de Henares, Adelaide and Sydney between 1996 and 2002 were inspired by the Italian Futurists, and Rios's website makes specific reference to the influence of Fillì's Tactile Dinner Party. Particularly noteworthy is her installation Cena de los 9 Vacios (9 Absences Dinner), performed in the gallery VACIO 9 in Madrid in 2002. ${ }^{11}$ Like the sensory concerts, Cena de los 9 Vacios participates in Rios's ongoing exploration of food art and the multisensorial, placing diners in

\footnotetext{
${ }^{11}$ I am very grateful to Alicia for an instructive correspondence in the spring of 2016, and to Bárbara Ortiz for sharing documentation of Cena de los 9 Vacios.
} 
a darkened room to evoke notions of emptiness, and serving them a 'black meal' consisting of red wine, black caviar and tapenade, among other richly shaded consumables (Rios 2015). ${ }^{12}$

Cena de los 9 Vacios is not strictly a theatre performance: it is a food art event set in very low light. But the food nonetheless plays at being something other, adopting a theatrical quality that deals in metaphors of darkness. The red wine, black caviar and tapenade are all material things that can be seen in dim candlelight, taking on a representational value that adds something more to sustenance. They are composed objects that offer themselves up to the diner's interpretative capacity who must work to connect meaning to sensation and a holistic mode of appearance that appeals to all of the senses, and that refuses to allow for any one sense or cognitive capacity to assert primacy over any other.

Darkness is as susceptible to objectification as any other prospective commodity, especially in postindustrial societies where growth in the immaterial consumption of experiences tie in with rises in immaterial production. However, while the doubleness that Ríos experiments with in her theatrical food art is not innocent of ideology - the kinds of food being served are quintessentially elitist - it builds on and at the same time makes strange a familiar process; darkness is 'reified' in the food, but a perceptual, cognitive and social encounter both with it and through it invites the perceiving subject to draw connections between the material, the immaterial, and the representational. The diner consumes the reified labour of an artist, but reification as a process emerges as a point of engagement for the consuming audience member as they are invited to connect, on their own exploratory paths, the terrain of the sensory, the social and the representational. What's more, in flickering candlelight the contours and crevices of faces and bodies morph, and the appearance of diners to one another is made strange not

\footnotetext{
${ }^{12}$ The idea for a 'black meal' was inspired by an eccentric funeral feast depicted in Joris-Karl Huysmans's $\grave{A}$ Rebours (Against Nature) (1884) (see Huysmans 2003: 13).
} 
because they can't be seen, but because their appearance is affected by a darkness that dances. This, I think, signals the potential of the threshold between food art and theatre as a space for experimentation with the aesthetics of darkness. By appealing to the interpretative capacities of her diners, Ríos unsettles the reifying tendencies of dining in the dark not by romanticizing invisible Others, but by subtly shifting acts and objects of perception into an aesthetic playspace that allows darkness to orientate as well as disorientate, and that allows for food to perform.

\section{Conclusion}

The commercialization and globalization of electric light impacted the evolution of art history, inspiring one of the most radical avant-garde movements of the twentieth century. While Italian Futurism tended to celebrate the virtues of electric light, Fillìa's Tactile Dinner Party took a different path by experimenting with acts and objects of perception under cover of darkness. It was an experiment that sat between food art and theatre, anticipating the co-evolution of dining in the dark and theatre in the dark in the 1990s. Reilhac's participation in Dark/Noir provided a model for dining in the dark that guided the establishment of permanent and commerciallyrun social enterprises like Dans Le Noir? However, several artists and companies have since proposed alternative models more akin to Fillìa's maverick experiment. Ríos's Cena de los 9 Vacios is one such example, albeit one that will not satisfy theatre in the dark purists; however, it is not completeness that teases out the potential radicalism of darkness in the contemporary moment, or the fact and novelty of sensory deprivation, but how darkness is approached and handled as an immaterial aesthetic that allows us to re-think and sense the material world. 


\section{References}

Althusser, L. (2005), For Marx, trans. B. Brewster, London: Verso.

Berghaus, G. (2001), ‘The Futurist Banquet: Nouvelle Cuisine or Performance Art?’, New Theatre Quarterly, 17 (1) (Feb.): 3-17.

Berghaus, G. (2009), 'Futurism and the Technological Imagination Poised Between Machine Cult and Machine Angst', in G. Berghaus (ed.), Futurism and the Technological Imagination, Amsterdam: Rodopi: 1-39.

Berman, M. (1983), All that is Solid Melts Into Air: The Experience of Modernity, London:

Verso.

Bewes, Timothy (2002) Reification, or The Anxiety of Late Capitalism, London and New York: Verso.

Blindekuh (2015), 'blindekuh - more than a restaurant'. Available online: http://www.blindekuh.ch/en/blindekuh_zuerich/who_we_are/press_releases/ (accessed 10 Aug. 2015).

Butler, J. (2008), ‘Taking Another's View: Ambivalent Implications', in A. Honneth, Reification: A New Look at an Old Idea, ed. M. Jay, Oxford: Oxford University Press: 97-119.

Chari, A. (2015), A Political Economy of the Senses: Neoliberalism, Reification, Critique, New York: Columbia University Press 
شوف الناس بقلبك في | Coca-Cola Middle East (2015), 'Remove labels this Ramadan

رمضان,, $\quad$ YouTube, 4 July $2015 . \quad$ Available at: https://www.youtube.com/watch?v=84OT0NLlqfM (accessed 6 Oct. 2015).

Crary, J. (2013) 24/7: Late Capitalism and the Ends of Sleep, London and New York: Verso.

Dans Le Noir (2014), 'Around the World'. Available at:

http://www.danslenoir.com/franchises/around-the- world.en.html (accessed 2 January 201.

de Broglie, E. (2015), Skype interview with the author, 13 Aug. 2015.

Edensor, T. and E. Falconer (2015), 'Dans Le Noir? Eating in the dark: sensation and conviviality in a lightless place', Cultural Geographies 22 (4): 601-18.

Elcott, N. M. (2016), Artificial Darkness: An Obscure History of Modern Art and Media, Chicago and London: University of Chicago Press.

Essex-Lopresti, S. (2015), Personal interview, Royal Festival Hall, London, 6 October 2015.

Gent, M. (2014), Personal interview, Spinach, London, 6 October 2014.

Hardt, M. (1999), 'Affective Labour', Boundary 2, 26 (2): 89-100.

Hausman, W. J., P. Hertner and M. Wilkins (2008), Global Electrification: Multinational

Enterprise and International Finance in the History of Light and Power, 1878-2007, New York: Cambridge University Press.

Hobkinson, C. (2014), 'An Aerobanquet at the 24ft Slow Speed Windtunnel Building 
Q121, Farnborough', 21 June 2014, Stirring with knives. Available at: http://www.stirringwithknives.com/ (accessed 29 Dec. 2015).

Hochschild, A. R. (1983), The Managed Heart: Commercialization of Human Feeling, $2^{\text {nd }}$ ed., London: University of California Press.

Honneth, A. (2008), Reification: A New Look at an Old Idea, trans. J. Ganahl, ed. M. Jay, Oxford: Oxford University Press.

Huysmans, J-K., (2003), Against Nature (A Rebours), trans. Robert Baldick, London: Penguin. Illouz, E. (2007), Cold Intimacies: The Making of Emotional Capitalism, Cambridge: Polity Press.

Jay, M. (2012), 'Introduction', in A. Honneth, Reification: A New Look at an Old Idea, ed. M. Jay, Oxford: Oxford University Press: 3-13.

Kirby, M. (1971), Futurist Performance, New York: E. P. Dutton \& Co. Inc.

Kleege, G. (1999), Sight Unseen, New Haven: Yale.

Lukács, G. (1971), History and Class Consciousness, trans R. Livingstone, London: Merlin Press.

Machedo, L. (2015), 'Coca-Cola "Remove Labels This Ramadan” Behind-The-Scene with Loy Machedo', LOYMACHEDO: Personal Branding Strategist, 9 July 2015. Available at: http://www.loymachedo.com/2015/07/coca-cola-remove-labels-this-ramadanbehind-the-scene-with-loy-machedo/ (accessed 10 Oct. 2015).

Magee, B. and M. Milligan (1995), On Blindness: Letters between Bryan Magee and 
Martin Milligan, Oxford: Oxford University Press.

Marinetti, F. T. (2009a), 'Electrical Advertising Signs: An Open Letter to his Excellency

Mussolini', trans L. Rainey, in L. Rainey, C. Poggi and L. Wittman (eds), Futurism: An Anthology, New Haven: Yale University Press: 282.

Marinetti, F. T. (2009b) 'Let's Murder the Moonlight', trans L. Rainey, in L. Rainey, C. Poggi and L. Wittman (eds), Futurism: An Anthology, New Haven: Yale University Press: 5461.

Marinetti, F. T. (2009c) ‘Tactilism', trans Lawrence Rainey, in L. Rainey, C. Poggi and L. Wittman (eds), Futurism: An Anthology, New Haven: Yale University Press: 264-9.

Marinetti, F. T. (2014 [1932]) The Futurist Cookbook, trans. S. Brill, ed. L. Chamberlain, London: Penguin.

Marx, K. (1995), Capital: an Abridged Edition, ed. David McLellan, Oxford: Oxford University Press.

Marx, K. and F. Engels (2002), The Communist Manifesto, trans. S. Moore, London: Penguin.

Michalko, R. (1999), The Two-in-One: Walking with Smokie, Walking with Blindness, Philadelphia: Temple University Press.

Palermo, E. (2014) 'Who Invented the Light Bulb?', LiveScience, 15 Feb. 2014. Available at: http://www.livescience.com/43424-who-invented-the-light-bulb.html (accessed 17 Aug. 2015). 
Pietropaolo, D. (2009), 'Science and the Aesthetics of Geometric Splendour in Italian Futurism', in G. Berghaus (ed.), Futurism and the Technological Imagination, Amsterdam: Rodopi: 41-61.

Pine, B. J. and J. H. Gilmore (1999), The Experience Economy: Work is Theatre \& Every Business a Stage, Boston: Harvard Business School Press.

Rios, A. (2015) Alicia and Ali\&Cia - Food Artists. Available at: http://www.aliciarios.com/en/food/sensory-concerts.html (accessed 14 Sept. 2015).

Saerberg, S. (2007), 'The Dining in the Dark Phenomenon', Disability Studies Quarterly, 27 (3) (Summer): n.p.

Spence, C., C. Hobkinson, A. Gallace and B. Piqueras Fiszman (2013), 'A touch of gastronomy', Flavour 2 (14): 1-15.

Spence, C. and B. Piqueras-Fiszman (2012), 'Dining in the dark: Does food taste better in the dark?', The Psychologist, 25 (12) (December): 888-91.

Welton, M. (2013), 'The Possibility of Darkness: Blackout and Shadow in Chris Goode's Who You Are', Theatre Research International, 38 (1) (March): 4-19. 